\title{
ASPECTS OF FISHERY AND SPECIES COMPOSITION OF EDIBLE CRABS IN THE JAFFNA LAGOON
}

\section{K. CHITRAVADIVELU}

Department of Zoology, University of Jaffna, Jaffna.

(Date of receipt $\quad$ : 22 June 1993)

(Date of acceptance : 15 November 1993)

\begin{abstract}
The Jaffna lagoon is a shallow water body in Northern Sri Lanka. The main season for crab fishery in the lagoon is from June to December. Over $70 \%$ of crabs caught are by Parik Koodu, which is a baited trap. Neptunus pellagicus (Linnaeus), Charybdis annulata (Fabricius) and Scylla serrata (Forskale) are the three species of edible crabs in the lagoon. Of these, $N$. pellagicus is the dominant species with an average composition of $79.5 \%$ in 1991 and $60.0 \%$ in 1992, C. annulata comprized $18.6 \%$ and $38.6 \%$ of the catch during the corresponding period. Although most in demand, $S$. serrata accounted for only $1.9 \%$ and $1.4 \%$ during the same period.
\end{abstract}

During 1991 catch per unit of effort (CPUE) varied from $3.5 \mathrm{~kg} \mathrm{PKU}{ }^{-1}$ day $^{-1}$ to 17.5 $\mathrm{kg} \mathrm{PKU}^{-1}$ day $^{-1}$ giving an average of $8.7 \mathrm{~kg} \mathrm{PKU}^{-1}$ day $^{-1}$ while in 1992 the value varied from $3.9 \mathrm{~kg}$ PKU-1 day ${ }^{-1}$ to $14.6 \mathrm{~kg} \mathrm{PKU}^{-1}$ day $^{-1}$ with an average of $7.8 \mathrm{~kg} \mathrm{PKU}^{-1}$ day $^{-1}$. The sizes of $N$. pellagicus, $C$. annulata and $S$. serrata ranged from $52 \mathrm{~mm}$ $150 \mathrm{~mm}, 41 \mathrm{~mm}-85 \mathrm{~mm}$ and $63 \mathrm{~mm}-190 \mathrm{~mm}$ in carapace width, respectively.

Key words: Baited, trap, CPUE, edible crabs, fishery, Jaffna lagoon, species composition.

\section{INTRODUCTION}

The Jaffna lagoon is a shallow water body located in the Northern part of Sri Lanka, and lies between $79^{\circ} 52^{\prime} \mathrm{E}$ and $80^{\circ} 38^{\prime} \mathrm{E}$ longitude and $9^{\circ} 26^{\prime} \mathrm{N}$ and $9^{\circ} 46^{\prime} \mathrm{N}$ latitude. The lagoon has an area of approximately $421 \mathrm{~km}^{2}$ and the depth does not exceed four meters (Fig. 1). The lagoon is connected to the sea at Punnalai, between Karaitivu and Kayts and between Kalmunai and Mandaitivu. Tidal currents entering and flowing out through these channels effect mixing of water. ${ }^{1,2}$

Crabs have a high consumer demand and fetch a high price both here and abroad. Sri Lanka anticipates to earn rupees twenty seven million by export of crabs in $1994 .^{3}$ Crabs from the Jaffna lagoon were sent alive to Colombo for export by a Sea Food Collecting Centre, realizing around rupees twenty seven million as the value of first sale in 1990. Crabs form an increasingly important source of income to the fishermen of Jaffna. Though some studies have been carried out with regard to fisheries and hydrology of the Jaffna lagoon during the last two decades $1,2,4,5$ no work has been done on the crab fishery of the Jaffna lagoon. In Sri Lanka, Raphael ${ }^{6}$ has published her observations on the growth and survival of Scylla serrata under pond culture conditions in an area adjoining the Negombo lagoon while Jayamanna and Jinadasa ${ }^{7}$ have reported on the size at maturity and spawning periodicity of $S$. serrata in the Negombo estuary. 


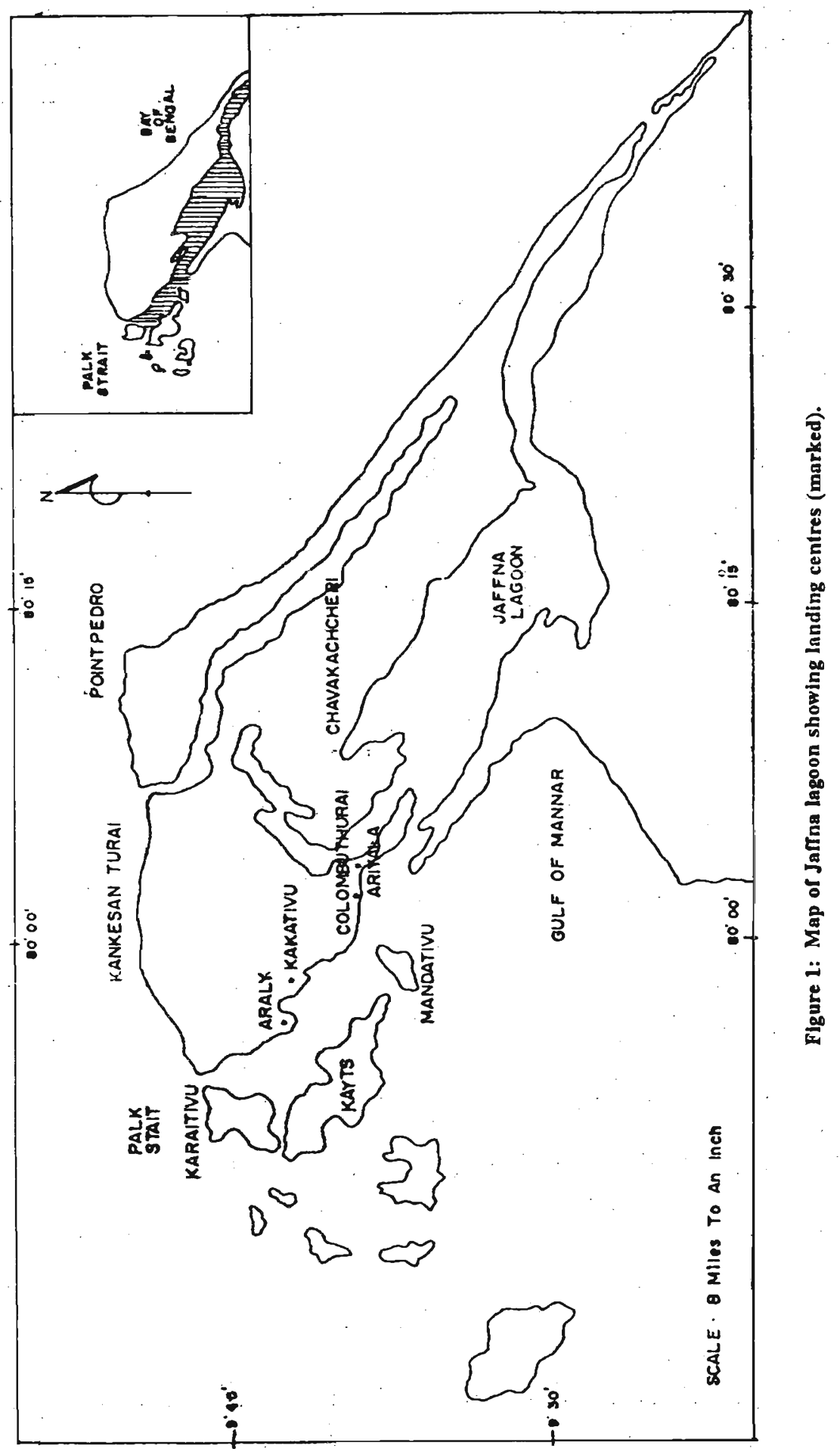


Fresh raw crab meat has been reported to have an approximate composition of $71-74 \%$ water, $19-24 \%$ protein, $0-6 \%$ fat and $1-2 \%$ minerals. ${ }^{8}$ The amount of meat extracted from crabs varies widely with the season and with the fishing ground. The meat yield is about $30 \%$ of the total body weight. ${ }^{8}$ The meat of crabs is relished as a delicacy and because of the high demand and commercial value, fishing activities for crabs have been intensive. Indiscriminate fishing for crabs, in the absence of management measures can however cause a decline in the crab population.

The present investigation initiated in January 1991 was an attempt to evaluate the state of crab fishery lagoon and determine the species composition of crabs in the Jaffna lagoon.

In the Jaffna lagoon crabs are caught by Parik Koodu (baited crab trap), Sirahu valai (stake net), Illuvai valai (Drag net), Kandi (cone cage or aproned cone cage), hoop net, drift nets (gill nets) and tramel nets (disco net). Sachithananthan and Thevathasan ${ }^{4}$ have reported on the structure and operation of Sirahu valai in the Jaffna lagoon. The structure and operation of drag net, Kandi and hoop net have been described in detail by Chitravadivelu. ${ }^{2}$ Pearson $^{9}$ in his description of fishing appliances of Ceylon refers to Parik Koodu but does not give a detailed description.

Parik Koodu is a box-like crab trap, measuring about $55 \mathrm{~cm} \times 90 \mathrm{~cm}$ and $30 \mathrm{~cm}$ high, constructed on a traditional design to allow entry of the crabs but to hinder their escape (Fig. 2). The trap is woven entirely of split rachis of Phoenix sp. and has a funnel or 'sokan' with an oval mouth with a longer diameter of $35 \mathrm{~cm}$ and a shorter diameter of $20 \mathrm{~cm}$. The longer diameter is positioned always vertically and the wide mouth at the outside provides easy entry for the crabs. The inner end of the funnel narrows, bends down and ends in an opening about $20 \mathrm{~cm}$ above the base of the trap, to prevent escape by re-entry into the funnel. The hexagonal mesh of the trap has a fixed diagonal length of $4.0 \mathrm{~cm}$.

The catching power of the trap primarily depends on the attraction of the bait. Almost any kind of fish or shellfish can be used as bait for crabs; but puffer fish (Arothron sp.), eel (Anguilla sp.) and skate (Mobula sp.) are used in Jaffna. The puffer fish, which has a very tough skin and lasts well in the trap, is a popular choice among the crab fishers in the Jaffna lagoon. The bait either as a whole specimen or as cut pieces, is tied on to the inside base of the trap, immediately below the opening of the 'sokan'. The traps are also weighed immediately below the opening of the 'sokan', by tieing two heavy stones inside at the base on diagonally opposite sides. 


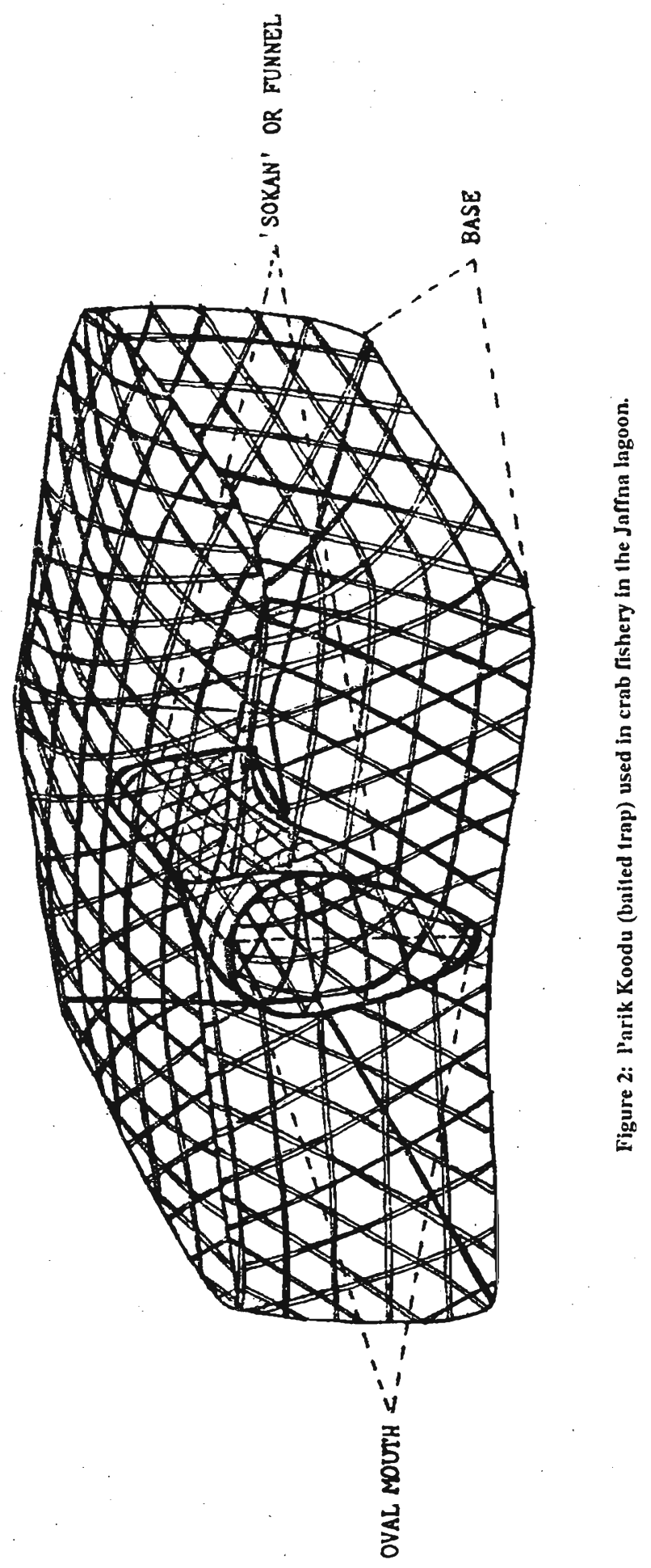


20-30 traps taken per boat, manned by two fishermen, are set in the morning at intervals of $3 \mathrm{~m}$ to $5 \mathrm{~m}$ in selected areas in the lagoon with a minimum depth of about $1 \mathrm{~m}$, left overnight and hauled the following morning, after about 24 hours. The catch is then removed, the traps rebaited and re-laid after effecting necessary repairs, on the spot. Although the number of traps in a set varies, to maintain uniformity, only samples from sets consisting of 20 traps were utilized. A set consisting of 20 traps is considered as a unit in the present investigation. 250-300 fishermen using Parik Koodu are permanently employed in crab fishery in the lagoon while about 1000 Sirahu valai operators engage in crab fishery during the peak of the season using Parik Koodu as a means of obtaining an additional income.

\section{METHODS AND MATERIALS}

The dimensions and mesh sizes of the gear used in this investigation are given in Table 1. Gear were either supplied or partly financed and cost of maintenance met by the investigator to maintain uniformity.

Random samples of crabs were taken from the landing centres from all gear at Araly, Kakaitivu, Columbuththurain and Ariyalai (Fig. 1), once a week as far as possible and were brought to the laboratory for detailed analysis and computation of species composition. Since preliminary observations during first three months indicated that over $70 \%$ of crabs caught were from Parik Koodu, the weights of the total catch of crabs from 3-5 units in each landing centre were recorded, for evalution of monthly trends in catches.

The average catch per unit of effort (CPUE) for each Parik Koodu Unit (PKU) for each month was calculated. CPUE was calculated taking an operation day as the unit of effort and expressed in live weight $\mathrm{kg} \mathrm{PKU}^{-1}$ day $^{-1}$.

The temperature of the air and surface water, $\mathrm{pH}$ and salinity were also recorded at each station at 8.00 a.m. Rainfall data was obtained from the Meteorological Office at Jaffna. The samples brought to the laboratory were first identified into species according to Lovett $^{10}$ and then separated into males and females. The live weight of each specimen was determined using a triple beam balance (Model 700) and recorded to the nearest milligram. The carapace width $(\mathrm{CW})$ was measured using a measuring board. The carapace width $(\mathrm{CW})$ is the distance between the tips of the last lateral spines. 
Table 1: Dimensions and mesh sizes of gear used in crab fishery in the Jaffna lagoon.

\begin{tabular}{|c|c|c|c|c|c|c|}
\hline \multirow[b]{2}{*}{ Gear } & \multirow[b]{2}{*}{ Components } & \multicolumn{5}{|c|}{ Dimensions in metres } \\
\hline & & No. in a unit & Length & $\begin{array}{l}\text { Breadth/ } \\
\text { *Height }\end{array}$ & Diameter & $\begin{array}{l}\text { Mesh size } \\
\text { in } \mathrm{mm}\end{array}$ \\
\hline Sirahu & Leader & 01 & 100 & 2.0 & - & 11.0 \\
\hline \multirow[t]{2}{*}{ valai } & Wing & & 15 & 2.0 & - & 11.0 \\
\hline & Chamber & & & 2.0 & 5.0 & 8.0 \\
\hline \multirow[t]{2}{*}{ Drag net } & Bag & 01 & 9.5 & 2.5 & - & 9.0 \\
\hline & Pouch & & 9.5 & 1.3 & - & 16.0 \\
\hline \multirow[t]{4}{*}{ Hoop net } & Cage & 10 & 4.0 & - & - & 10.0 \\
\hline & Large ring & & - & - & 0.5 & - \\
\hline & Large barrier & & 13.5 & 1.3 & - & 10.0 \\
\hline & Small barrier & 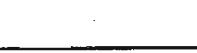 & 3.2 & 1.3 & - & 10.0 \\
\hline \multirow[t]{2}{*}{ Kandi } & Outer cone & 10 & 1.2 & - & 0.45 & 3.0 \\
\hline & Inner cone & & 0.7 & - & - & 3.0 \\
\hline Parik & Cage & 20 & 0.9 & $0.55 /^{*} 0.30$ & - & 40.0 \\
\hline \multirow[t]{2}{*}{ koodu } & Sokan longer & & - & - & 0.35 & 40.0 \\
\hline & Sokan shortẹ & & - & - & 0.20 & - \\
\hline Tramel & Outer nets & 01 & 27.0 & 2.0 & - & 256.0 \\
\hline net & Middle net & & 27.0 & 2.0 & - & 45.0 \\
\hline
\end{tabular}

The monthly trends of catches in terms of an average seasonal index ${ }^{2,11}$ of catches of crabs were determined taking the index as 100 when the observed catch is the same as the expected monthly mean and shown in Figure 3. The monthly mean is obtained by dividing the sum of the monthly average CPUE for Parik Koodu by twelve.

Two hundred and forty eight samples collected at the different landing centres of the Jaffna lagoon comprizing 31,834 crabs were analysed during the period of investigation.

A statistical analysis was utilized to see the relationship among the variables studied, i.e., a correlation matrix consisting the pairwise correlations between the variables defined for CPUE, air temperature, surface water temperature, $\mathrm{pH}$, salinity and rainfall. Then the multiple correlation co-efficient ( $R$ ) between CPUE and the combined effect of the other variables mentioned was calculated together with the F-statistic for significance. ${ }^{12}$ 


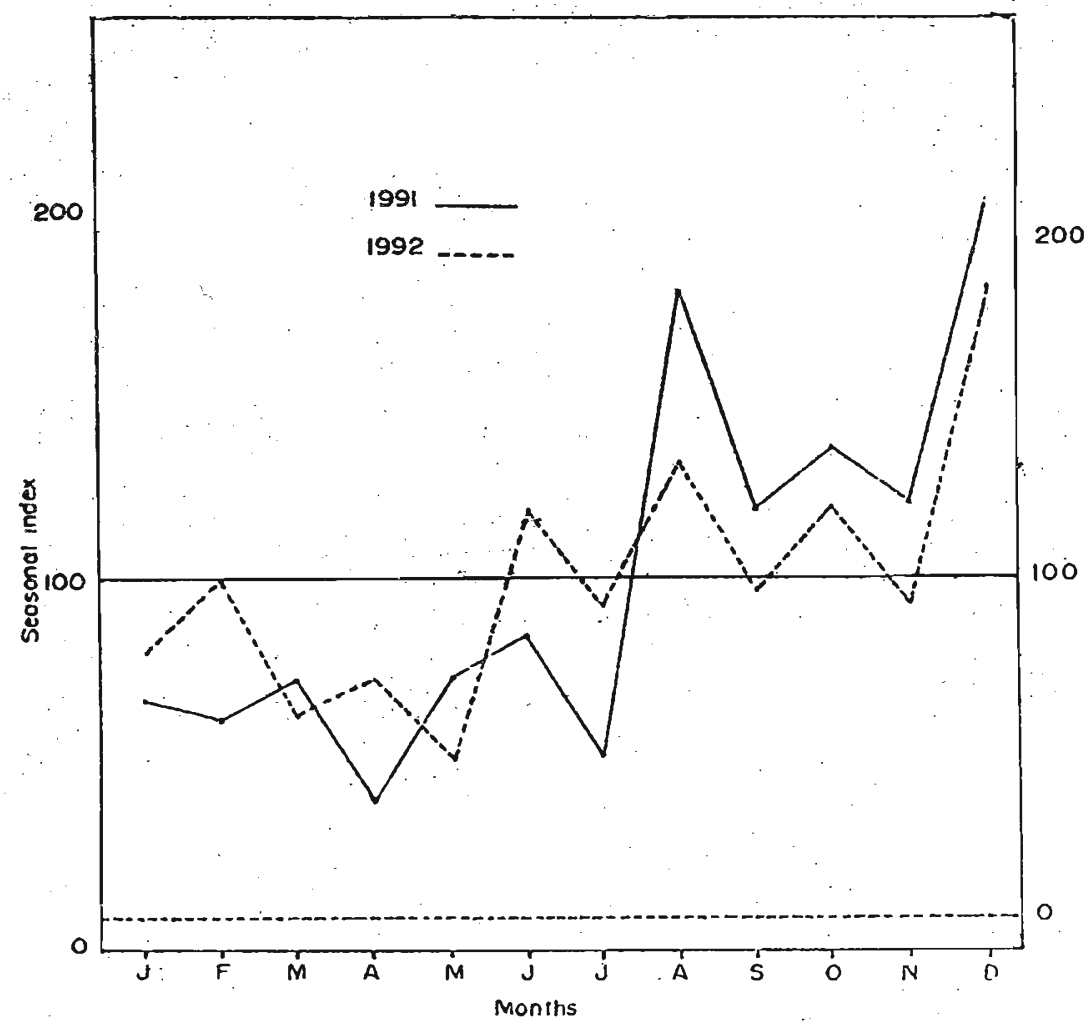

Figure 3 : Monthly trends of CPUE of crabs in the Jafrna lagoon in 1991 and 1992 using seasonal indices.

\section{RESULTS}

The monthly variations in air and surface water temperature in the Jaffna lagoon and rainfall in Jaffna during 1991 and 1992 are shown in Tables 3 and 4. The lowest air temperatures of $21.8^{\circ} \mathrm{C}$ and $26.0^{\circ} \mathrm{C}$ were in August 1991 and November 1992 respectively. The surface water temperatures varied from $20.4^{\circ} \mathrm{C}$ (August) to $29.9^{\circ} \mathrm{C}$ (February) in 1991 and $29.0^{\circ} \mathrm{C}$ (July) to $25.0^{\circ} \mathrm{C}$ (November) in 1992. The highest rainfall in 1991 was $378.3 \mathrm{~mm}$ in November. In 1992 the highest rainfall of $428.3 \mathrm{~mm}$ was also recorded in November. pH varied between 7.3 and 7.8 in 1991 and between 7.4 and 7.6 in 1992. The lowest salinity of $23.0 \mathrm{ppt}$ was recorded in December, 1991 and of $26.5 \mathrm{ppt}$ in January 1992. The highest salinity of $34 \mathrm{ppt}$ was in May 1991 and October 1992 (Fig. 4).

Three species of edible crabs - Neptunus pelagicus, Charybdis annulata and Scylla serrata were recorded from the catches in the Jaffna lagoon. The numbers of each species of crab in the samples for a month, from all landing centres were added and the monthly species compositions for 1991 and 1992 then computed (Table 2). Among the three species of edible crabs $-N$. pellagicus, $C$. annulata and $S$. serrata in 
the Jaffna lagoon, $N$. pellagicus with a mean species composition of $79.5 \%$ in 1991 and $60.0 \%$ in 1992 is the predominant species, followed by C. annulata with $18.6 \%$ and $38.6 \%$ in 1991 and 1992 respectively. S. serrata though the most popular species has a mean species composition of only $1.9 \%$ and $1.4 \%$ during the two years (Table 2).

The N. pelagicus catch was low in August 1991 and May 1992. with 47.1\% and $41.0 \%$ respectively. During these months the per cent composition of $C$. annulata was the highest with $51.8 \%$ and $56.0 \%$. The percentage composition of $S$. serrata varying from $0.7 \%$ in February 1991 to $4.6 \%$ in January 1991 recorded the highest percentage of only 3.0 in May 1992 (Table 2).

Table 2: Monthly variation of species composition of crabs from cumulative catches of all types of gear in the Jaffna Lagoon in 1991 and 1992.

\begin{tabular}{lllllll}
\hline & \multicolumn{5}{c}{ \% Species composition } \\
\cline { 2 - 7 } Species & \multicolumn{7}{c}{ N. pellagicus } & \multicolumn{3}{c}{ C. annulata } & \multicolumn{2}{c}{ S. serrata } \\
\hline Months & 1991 & 1992 & 1991 & 1992 & 1991 & 1992 \\
\hline Jan & 78.5 & 78.0 & 16.9 & 34.0 & 4.6 & 1.0 \\
Feb & 96.3 & 60.0 & 3.0 & 39.1 & 0.7 & 0.9 \\
Mar & 98.0 & 66.3 & 1.2 & 33.0 & 0.8 & 0.7 \\
Apr & 93.2 & 69.6 & 4.6 & 28.9 & 2.2 & 1.5 \\
May & 94.6 & 41.0 & 2.5 & 56.0 & 2.9 & 3.0 \\
Jun & 98.4 & 69.0 & 0.0 & 29.4 & 1.6 & 1.6 \\
Jul & 73.7 & 69.5 & 24.8 & 28.5 & 1.5 & 2.0 \\
Aug & 47.1 & 64.5 & 51.8 & 34.0 & 1.1 & 1.5 \\
Sep. & 70.3 & 61.5 & 28.0 & 36.0 & 1.7 & 1.5 \\
Oct & 81.5 & 47.0 & 16.4 & 52.0 & 2.1 & 1.0 \\
Nov & 70.8 & 45.0 & 28.0 & 54.0 & 1.2 & 1.0 \\
Dec & 51.4 & 61.6 & 45.9 & 33.3 & 2.7 & 1.1 \\
\hline Mean & 79.5 & 60.0 & 18.6 & 38.6 & 1.9 & 1.4 \\
SD & 17.67 & 10.04 & 17.63 & 10.03 & 1.09 & 0.63 \\
\hline
\end{tabular}

The monthly data of CPUE of crab for Parik Koodu Unit (PKU) in 1991 and 1992 are given in Tables 3 and 4.

The correlation matrices describing the interrelationship among the variables for 1991 and 1992 are given in Tables 5 and 6. The corresponding multiple correlation coefficients together with their F-statistics are also indicated. 
Table 3: Monthly variation of CPUE of Parik Koodu Unit (PKU) and environmental factors in the Jafrna lagoon in 1991.

\begin{tabular}{lcrcccr}
\hline \multirow{2}{*}{1991} & & \multicolumn{5}{c}{ Environmental Factors } \\
\cline { 3 - 7 } Months & $\begin{array}{c}\text { CPUE } \\
\text { kg PKU }^{-1} \text { day }^{-1}\end{array}$ & $\begin{array}{r}\text { Temp } \\
\text { air }^{0} \mathrm{C}\end{array}$ & $\begin{array}{c}\text { Temp surface } \\
\text { water }\end{array}{ }^{0} \mathrm{C}$ & $\mathrm{pH}$ & Salinity & Rainfall \\
Jan & 5.8 & 30.5 & 28.5 & 7.5 & 25.0 & mm \\
Feb & 5.3 & 32.4 & 29.9 & 7.7 & 25.5 & 50.7 \\
Mar & 6.2 & 29.7 & 27.9 & 7.3 & 26.0 & 12.3 \\
Apr & 3.5 & 30.2 & 29.1 & 7.5 & 28.5 & 57.7 \\
May & 6.3 & 33.0 & 27.0 & 7.3 & 34.0 & 1.4 \\
Jun & 7.3 & 28.1 & 26.7 & 7.5 & 30.5 & 47.0 \\
Jul & 4.6 & 29.9 & 28.0 & 7.7 & 31.0 & 3.5 \\
Aug & 15.4 & 21.8 & 20.4 & 7.8 & 27.0 & 59.4 \\
Sep & 10.2 & 28.5 & 24.0 & 7.5 & 25.0 & 39.2 \\
Oct & 11.7 & 30.5 & 29.0 & 7.6 & 28.5 & 256.5 \\
Nov & 10.4 & 29.5 & 28.5 & 7.7 & 26.5 & 378.3 \\
Dec & 17.5 & 28.0 & 26.5 & 7.6 & 23.0 & 179.8 \\
\hline Mean & 8.7 & 29.3 & 27.1 & 7.6 & 27.6 & 97.9 \\
SD & 4.4 & 2.8 & 2.6 & 0.2 & 3.2 & 115.8 \\
\hline
\end{tabular}

Table 4: Monthly variation of CPUE of Parik Koodu Unit (PKU) and environmental factors in the Jaffna lagoon in 1992.

\begin{tabular}{lcccccr}
\hline \multirow{2}{*}{1992} & & \multicolumn{5}{c}{ Environmental Factors } \\
\cline { 3 - 7 } Months & $\begin{array}{c}\text { CPUE } \\
\text { kg PKU }\end{array}$ day $^{-1}$ & $\begin{array}{c}\text { Temp } \\
\text { air }{ }^{0} \mathrm{C}\end{array}$ & $\begin{array}{c}\text { Temp Surface } \\
\text { water }{ }^{0} \mathrm{C}\end{array}$ & $\mathrm{pH}$ & $\begin{array}{c}\text { Salinity } \\
\mathrm{ppt}\end{array}$ & $\begin{array}{c}\text { Rainfall } \\
\text { mm }\end{array}$ \\
\hline Jan & 6.1 & 29.3 & 27.5 & 7.5 & 26.5 & 2.1 \\
Feb & 7.8 & 28.1 & 25.0 & 7.4 & 27.0 & 0.0 \\
Mar & 4.6 & 29.0 & 26.0 & 7.4 & 27.0 & 0.0 \\
Apr & 5.5 & 28.1 & 25.5 & 7.4 & 27.5 & 35.8 \\
May & 3.9 & 28.0 & 26.0 & 7.5 & 27.4 & 66.3 \\
Jun & 9.4 & 27.0 & 27.0 & 7.6 & 28.5 & 7.8 \\
Jul & 7.2 & 31.0 & 29.0 & 7.6 & 32.3 & 0.8 \\
Aug & 10.5 & 30.0 & 28.0 & 7.6 & 34.0 & 37.0 \\
Sep & 7.6 & 29.5 & 28.5 & 7.5 & 33.5 & 57.3 \\
Oct & 9.5 & 29.0 & 28.0 & 7.5 & 31.5 & 222.9 \\
Nov & 7.2 & 26.0 & 25.0 & 7.6 & 30.0 & 428.3 \\
Dec & 14.6 & 26.8 & 26.6 & 7.5 & 30.8 & 78.6 \\
\hline Mean & 7.8 & 28.5 & 26.8 & 7.5 & 29.7 & 78.0 \\
SD & 2.9 & 1.4 & 1.4 & 0.08 & 2.7 & 126.7 \\
\hline
\end{tabular}


During 1991, CPUE varied from $3.5 \mathrm{~kg} \mathrm{PKU}^{-1}$ day $^{-1}$ to $17.5 \mathrm{~kg} \mathrm{PKU}^{-1}$ day $^{-1}$ giving a mean of $8.7 \mathrm{~kg} \mathrm{PKU}^{-1}$ day $^{-1}$ while in 1992 the value varied from $3.9 \mathrm{~kg} \mathrm{PKU}^{-1} \mathrm{day}^{-1}$ to $14.6 \mathrm{~kg} \mathrm{PKU}^{-1}$ day $^{-1}$ with a mean of $7.8 \mathrm{~kg} \mathrm{PKU}^{-1}$ day ${ }^{-1}$.

The maximum size of male and female the $N$. pellagicus, C. annulatea and $S$ serrata crabs caught in the Jaffna lagoon were respectively of carapace width $138 \mathrm{~mm}$ and $150 \mathrm{~mm}, 85 \mathrm{~mm}$ and $75 \mathrm{~mm}, 179 \mathrm{~mm}$ and $190 \mathrm{~mm}$. The corresponding weights were respectively $208 \mathrm{gm}$ and $300 \mathrm{gm}, 135 \mathrm{gm}$ and $120 \mathrm{gm}$ and $910 \mathrm{gm}$ and $1090 \mathrm{gm}$.

\section{DISCUSSIONS}

A wide variety of methods are used to catch crabs, but gear relying on the use of bait bave been most effective, both in regard to catch efficiency and fishery management. ${ }^{13}$ Parik Koodu is an artisanal trap of this type that rests on the floor of the sea. The success of baited gear of this design depends largely in the omnivorous, scavenging feeding behaviour of crabs. The trap when baited, lures crabs into the trap from which escape is prevented. The fact that crabs spend most of their time crawling on the bottom simplifies the catch efforts, in baited gear like Parik Koodu that rest on the bottom. ${ }^{13}$

The catch per unit of effort (CPUE) is used as an index of stock in the water body. ${ }^{14}$ The knowledge of a good estimate of fishing effort in one of the essential conditions to the assement of the management. ${ }^{15}$ The stock and consequently the CPUE depend on a variety of environmental factors such as temperature, $\mathrm{pH}$, salinity, rainfall and fishing pressure.

Multiple correlation analysis revealed that the CPUE was influenced by the combined effect of physio-chemical factors in both years. Co-efficients (R) for 1991 and 1992 show that the relationship is significant. The F-statistical values support the significance of the multiple correlation co-efficients $(\mathrm{P}<0.05)$. Further the correlation matrices of both years show that the air temperature is highly negatively correlated with CPUE. Also the salinity seems to be highly positively correlated with CPUE (Tables 5 and 6).

The mean monthly CPUE values of Parik Koodu Unit in 1991 and 1992 indicate that the main season for crab fisheries extends from June to December with peak catches during this period (Tables 3 and 4). Taking the seasonal indices of CPUE of Parik Koodu for 1991 and 1992, on the whole August to December could be considered as substantially productive months, as far as the crab fishery in the Jaffna lagoon is concerned.

CPUE values of $17.5 \mathrm{~kg} \mathrm{PKU}^{-1} \mathrm{day}^{-1}$ for December 1991 and $14.6 \mathrm{~kg} \mathrm{PKU}^{-1}$ day $^{-1}$ for December 1992 indicate that December is the most productive month. On the 
whole 1991 was a more productive year than 1992 in terms of crab fishery in the Jaffna lagoon as reflected by the average CPUE in Parik Koodu which is the dominant gear in crab fishery. The monthly trends of crab catches in Parik Koodu reflected by the seasonal indices (Fig. 3), show more or less the same trend for 1991 and 1992.

Although $S$. serrata is the most popular species with great economic potential among the edible crabs in the Jaffna lagoon, its composition in catches was less than $2 \%$ during the period under investigation.

Table 5: Correlation matrix, multiple correletion coefficient and F-statistic for 1991.

\begin{tabular}{|c|c|c|c|c|c|c|}
\hline & \multicolumn{6}{|c|}{ Correlation coefficients } \\
\hline & CPUE & $\begin{array}{c}\text { Air } \\
\text { temperature }\end{array}$ & $\begin{array}{c}\text { Surface } \\
\text { temperature }\end{array}$ & $\mathrm{pH}$ & Salinity & Rainfall \\
\hline$\overline{\mathrm{CPUE}}$ & & & & & & \\
\hline Air temp. & -0.6447 & & & & & \\
\hline Sur. temp. & -0.5931 & +0.8490 & & & & \\
\hline $\mathrm{pH}$ & +0.3979 & +0.4798 & -0.2252 & & & \\
\hline Salinity & +0.4390 & +0.2828 & +0.0782 & -0.2833 & & \\
\hline Rainfall & +0.4673 & -0.0291 & +0.2200 & +0.3849 & -0.3139 & \\
\hline & $\mathrm{R}=0.8765$ & & $F=0.1105$ & & & \\
\hline
\end{tabular}

Table 6: Correlation matrix, multiple correlation coefficient and F-statistic for 1992.

\begin{tabular}{|c|c|c|c|c|c|c|}
\hline & \multicolumn{6}{|c|}{ Correlation co-efficients } \\
\hline & CPUE & $\begin{array}{c}\text { Air } \\
\text { temperature }\end{array}$ & $\begin{array}{c}\text { Surface } \\
\text { temperature }\end{array}$ & $\mathrm{pH}$ & Salinity & Rainfall \\
\hline \multicolumn{7}{|l|}{ CPUE } \\
\hline Air temp. & -0.2034 & & & & & \\
\hline Sur. temp. & +0.2536 & +0.7390 & & & & \\
\hline $\mathrm{pH}$ & +0.3374 & +0.0253 & +0.4739 & & & \\
\hline Salinity & +0.5285 & +0.3754 & +0.6869 & +0.5774 & & \\
\hline Rainfall & +0.0580 & -0.5106 & -0.2678 & +0.3258 & +0.2064 & \\
\hline & \multicolumn{3}{|c|}{$\overline{\mathrm{R}}=0.8292$} & $=0.0733$ & & \\
\hline
\end{tabular}

Prasad and Tampi ${ }^{16}$ have recorded male and female $N$. pelagicus of maximum carapace width of $182 \mathrm{~mm}$ and $167 \mathrm{~mm}$ respectively in the crab landings at Vedalai, India. S. serrata specimens as large as $190 \mathrm{~mm}$ for males and $165 \mathrm{~mm}$ for females have been reported from natural habitat by Stephenson and Camphell ${ }^{5}$ while 
Macintosh ${ }^{17}$ has reported specimens of $200 \mathrm{~mm}$ without reference to sex. Jayamanna and Jinadasa ${ }^{7}$ have reported berried females of carapace length around $98.0 \mathrm{~mm}$ to $130 \mathrm{~mm}$ in the Negombo estuary. Though the maximum sizes of $S$. serrata from the Jaffna lagoon agree well with those reported, $N$. pelagicus are smaller than those reported by Prased and Tempi. ${ }^{16}$

\section{Acknowledgement}

The author is grateful to S. Kuganathan and K. Somasundaram of the Department of Zoology, University of Jaffna for assistance and the University of Jaffna for research support.

\section{References}

1. Sachithanantham K. \& Perera W.K.T. (1970). Topography and substratum of the Jaffna lagoon. Bulletin of the Fisheries Research Station, Ceylon 21(2): 75-85.

2. Chitravadivelu K. (1990). Efficiency of the main fishing gears used in prawn fishery in the Jaffna lagoon. Joumal of the National Science Council of Sri Lanka $18(1): 37-52$.

3. National Fisheries Development Plan (1990). Ministry of Fisheries, Colombo 1990-1994. pp. 1-14.

4. Sachithanantham K. \& Thevathasan A. (1970). Sirahu valai - a passive gear in Ceylon. Bulletin of the Fisheries Research Station, Ceylon 21(2): 87-95.

5. Stephenson W. \& Camphell B. (1960). The Australian Portunids (Crustacea: Portunidae). IV. Remaining genera. Australian Joumal of Marine and Freshwater Resoitres 11(1): 114.

6. Raphael Y.I. (1970). A preliminary report on the brackish water pond culture of Scylla serrata (Forskal) in Ceylon. Symposium, Indo-Pacific Fisheries Council, FAO. 14th session, Bangkok, Thailand. 18-27 Nov. 1970. 14: 1-10.

7. Jayamanna S.C. \& Jinadasa J. (1993). Size at maturity and spawning periodicity of the mud crab Scylla serrata (Forskal) in the Negombo estuary. Journal of the National Science Council of Sri Lanka 21(1): 141-152.

8. Edwards E. \& Early J.C. (1987). Catching, handling and processing crabs. Torry Advisory Note No. 26 (revised). Ministry of Aquaculture, Fisheries and Food, Torry Research Station, UK. pp. 1-16.

9. Pearson J. (1923). Fishing appliances of Ceylon. Bulletin of the Fisheries Research Station 3: 1-132. 
10. Lovett D.L. (1981). A guide to the shrimps, prawns, lobsters and crabs of Malaysia and Singapore. Faculty of Fisheries and Marine Sciences, University of Pertanian, Malaysia. Occasional Publication 2: 106-149.

11. Rossi R. (1984). Management of aquaculture and fishing in the Scardovari Fishery (Poriver Delta, Italy). In: Management of Coastal Lagoon Fisheries. (Ed. J. M. Kapetsky) 61(2): 441-458.

12. Morrison D.F. (1990). Multivariate statistical methods. (3rd edition.) pp. 94-108. McGrow-Hill International, Singapore.

13. Haefner P.A. (1985). The biology and exploitation of crabs. In: The biology of Cristacea . Economical aspects : Fisheries and culture (Ed. A.J. Provenzano Jr.) 10: 111-166.

14. Cushing D.H. (1981). Fisheries biology - A study in population dynamics. The University of Wisconsin Press. pp. 223.

15. Garcia S. \& Reste L. (1981). Life cycles, dynamics, exploitation and management of coastal Penaeid shrimp stocks. FAO Fisheries Technical Paper No. 203. pp. 215.

16. Prasad R.K. \& Tampi P.R.S. (1953). A contribution to the biology of the blue swimming crab, Neptunus pelagicus (Linnaeus) with a note on the zoea of Thalamita crenata latereille. Journal of the Bombay Natural History Society 51: 673-689.

17. Macintosh D.J. (1982). Fisheries and aquaculture significance of mangrove swamps, with special reference to the Indo-West Pacific Region. In: Recent Advances in Aquaculture (Eds. J.F. Muir \& R.J. Roberts). pp. 1-85. Westview Press, Boulder, Colorado. 